Western Washington University

Western CEDAR

$1-1986$

\title{
Ventilation, Gas Exchange, and Aerobic Scope in a Small Monitor Lizard, Varanus gilleni
}

Philip E. Bickler

Roger A. Anderson

Western Washington University, roger.anderson@wwu.edu

Follow this and additional works at: https://cedar.wwu.edu/biology_facpubs

Part of the Biology Commons

\section{Recommended Citation}

Bickler, Philip E. and Anderson, Roger A., "Ventilation, Gas Exchange, and Aerobic Scope in a Small Monitor Lizard, Varanus gilleni" (1986). Biology Faculty and Staff Publications. 37.

https://cedar.wwu.edu/biology_facpubs/37

This Article is brought to you for free and open access by the Biology at Western CEDAR. It has been accepted for inclusion in Biology Faculty and Staff Publications by an authorized administrator of Western CEDAR. For more information, please contact westerncedar@wwu.edu. 


\section{CHICAGO JOURNALS}

Division of Comparative Physiology and Biochemistry, Society for Integrative and Comparative Biology

Ventilation, Gas Exchange, and Aerobic Scope in a Small Monitor Lizard, Varanus gilleni Author(s): Philip E. Bickler and Roger A. Anderson

Source: Physiological Zoology, Vol. 59, No. 1 (Jan. - Feb., 1986), pp. 76-83

Published by: The University of Chicago Press. Sponsored by the Division of Comparative

Physiology and Biochemistry, Society for Integrative and Comparative Biology

Stable URL: http://www.jstor.org/stable/30156093

Accessed: 20/01/2015 18:36

Your use of the JSTOR archive indicates your acceptance of the Terms \& Conditions of Use, available at

http://www.jstor.org/page/info/about/policies/terms.jsp

JSTOR is a not-for-profit service that helps scholars, researchers, and students discover, use, and build upon a wide range of content in a trusted digital archive. We use information technology and tools to increase productivity and facilitate new forms of scholarship. For more information about JSTOR, please contact support@ jstor.org. 


\title{
VENTILATION, GAS EXCHANGE, AND AEROBIC SCOPE IN A SMALL MONITOR LIZARD, VARANUS GILLENI ${ }^{1}$
}

\author{
PHILIP E. BICKLER ${ }^{2,3}$ AND ROGER A. ANDERSON
}

Department of Biology, University of California, Los Angeles, Los Angeles, California 90024

(Accepted 7/11/85)

\begin{abstract}
Standard rates of $\mathrm{O}_{2}$ consumption $\left(\mathrm{V}_{2}\right)$ in the dark of Varanus gilleni (mean mass $=30 \mathrm{~g})$ were measured at $25,31,34$, and $37 \mathrm{C}$. At $37 \mathrm{C}$, the mean value $\left(195 \mathrm{ml} \mathrm{O}_{2}\right.$ STPD $\mathrm{kg}^{-1} \mathrm{~h}^{-1}$ ) was $22 \%$ lower than that predicted by a regression equation for lizards as a group (Bennett and Dawson 1976). Despite appearing to be asleep, three- to fourfold elevations in standard $\mathrm{V}_{2}$ were seen in lizards with lightweight, transparent respiratory masks. $\dot{\mathrm{VO}}_{2}$ was also measured during treadmill exercise at speeds from 5 to $15 \mathrm{~m} \mathrm{~min}^{-1}$ and during bouts of maximal exercise. Varanus gilleni has the highest factorial aerobic scope (27.5) of any lizard examined to date. The cost of transport in $V$. gilleni is relatively high and may relate to short limb length. Pulmonary ventilation and gas exchange $\left(\dot{\mathrm{V}}\right.$, $\left.\dot{\mathrm{V}} \mathrm{O}_{2}, \dot{\mathrm{V}} \mathrm{CO}_{2}\right)$ were simultaneously measured at $25 \mathrm{C}$, during warming from 25 to $35 \mathrm{C}$, and again after several hours at $35 \mathrm{C}$. Air-convection requirements for $\mathrm{CO}_{2}$ and $\mathrm{O}_{2}$ were independent of temperature. The patterns of lung ventilation suggest that arterial $\mathrm{PCO}_{2}$ and $\mathrm{pH}$ are constant with rising temperature, behavior that is common to that in large varanids and in contrast to that in other reptiles.
\end{abstract}

\section{INTRODUCTION}

Lizards of the family Varanidae are generally considered to exceed the capabilities of lizards of other families in the ability to sustain intense aerobic exercise. The varanid characteristics of high hematocrit and efficient $\mathrm{O}_{2}$ uptake from lung gas to blood and from blood to tissues correlate with their high aerobic scopes for exercise (Bennett 1973; Gleeson 1981). However, data for these generalizations come exclusively from a few large species $(\sim 1 \mathrm{~kg}$; see Gleeson 1981). Currently, it is not known whether these functional capabilities are shared by the smaller members of the family.

The relationships of body size to standard oxygen consumption $\left(\dot{\mathrm{V}}_{2}\right)$ and to $\dot{\mathrm{V}}_{2}$ during maximal exertion in varanids is not clear. There are several reports of elevated

\footnotetext{
${ }^{1}$ We would like to thank David Morafka and Bob Drewes for loan of the lizards. Equipment was generously loaned by G. A. Bartholomew. This work was supported by a Chancellor's Patent Fund Grant to P.E.B. from UCLA.

${ }^{2}$ Present address: Physiological Research Laboratory, Scripps Institution of Oceanography, A-004, University of California, San Diego, La Jolla, California 92093.

${ }^{3}$ Order of authorship decided by coin flip.
}

Physiol. Zool. 59(1):76-83. 1986.

(C) 1986 by The University of Chicago. All rights reserved. 0031-935X/86/5901-4122\$02.00 standard $\dot{\mathrm{V}}_{2}$ in larger varanids (Bartholomew and Tucker 1964; Wood et al. 1978), but other measurements of standard $\dot{\mathrm{VO}}_{2}$ of large varanids fall on the regression of body mass and $\mathrm{V}_{2}$ of lizards as a group (Bennett 1972; Gleeson 1980).

Lung ventilation in large varanids responds to changes in body temperature in a different way than has been reported for lizards of other families: the ratio of minute volume ( $\dot{\mathrm{V}})$ to $\dot{\mathrm{V}}_{2}$ is independent of temperature (Wood, Glass, and Johansen 1977; Wood et al. 1981). This pattern achieves a relatively constant $\mathrm{O}_{2}$ extraction efficiency over a range of temperature as well as a relatively constant lung $\mathrm{PO}_{2}$. It has been suggested that the relatively constant lung $\mathrm{PO}_{2}$ serves to support $\mathrm{O}_{2}$ delivery to tissues during activity (Wood et al. 1977). These patterns of ventilation may also produce a relatively constant relationship between lung $\mathrm{PCO}_{2}$ and body temperature. The constant lung $\mathrm{PCO}_{2}$ is reflected in temperatureindependent arterial $\mathrm{PCO}_{2}$ and hence in relatively constant arterial $\mathrm{pH}$ despite temperature changes (Wood et al. 1981).

The present study was done to see whether some of the physiological features of large varanids are shared by one of the smallest members of the family. The lizard we studied, the pigmy mulga monitor (Varanus gilleni) is small $(<0.1 \mathrm{~kg})$, secretive, and thigmothermic (i.e., it obtains heat 
from warm substrates) (Pianka 1969). This arboreal species is found under the bark of trees in the deserts of central Australia. It preys principally on large arthropods and small arboreal gekkos. Although field-active body temperatures have not been reported for this species, varanids of similar ecology and body size have body temperatures while active of 37-38 C (Pianka 1969). We measured standard $\dot{\mathrm{VO}}_{2}, \dot{\mathrm{VO}}_{2}$ during treadmill and maximal exercise, respiratory exchange ratios, and patterns of pulmonary ventilation at different body temperatures.

\section{MATERIAL AND METHODS}

For 30 days prior to the study in spring 1981, four Varanus gilleni of mass 20-40 $\mathrm{g}$ (held in captivity for $1 \mathrm{yr}$ ) were kept in large glass terraria under $12 \mathrm{~L}: 12 \mathrm{D}$ photoperiods. A 2,000-w photoflood lamp placed above one end of each terrarium provided light and heat during photophase. Lizards thermoregulated freely at a body temperature $\left(T_{\mathrm{b}}\right)$ of $\sim 37 \mathrm{C}$. At night $T_{\mathrm{b}}$ dropped to ambient temperature, $\sim 25 \mathrm{C}$. All lizards were fed a diet of mealworms, crickets, and small lizards; water was continuously available.

\section{STANDARD METABOLISM}

Standard rates of $\dot{\mathrm{V}}_{2}$ (standard metabolic rate [SMR]) were measured in the dark, during apparent sleeping behavior in the first half of normal scotophase. The lizards were not fed for 2-3 days before a trial. The lizards were placed unrestrained in respiratory chambers $3-4 \mathrm{~h}$ before a trial. SMRs were also measured in lizards treated identically except for being fitted with a lightweight, airtight plastic mask fitted with inflow and outflow lines. We used an opencircuit respirometry system. Dried, $\mathrm{CO}_{2-}$ free air was drawn through either the respirometry cylinders $(8 \mathrm{~cm}$ diam. $\times 20 \mathrm{~cm}$ length) or the mask of lizards placed into the cylinders. The flow then passed to a pump, a Brooks Rotameter flowmeter calibrated against a Brooks Thermal Mass Flowmeter, and to the analysis cell of an Applied Electrochemistry $\mathrm{O}_{2}$ analyzer equipped with dual sensors. Reference flow was also dry and $\mathrm{CO}_{2}$ free. $\mathrm{VO}_{2}$ was calculated according to the equations of Withers (1977). The entire analysis system was located in a constant-temperature room maintained at either $25,31,34$, or $36-37$ C. We weighed the lizards and took their cloacal temperature immediately after each trial. Rates of oxygen consumption reported represent the means of values obtained every $5 \mathrm{~min}$ for $2-3 \mathrm{~h}$. The lizards appeared to be asleep during the entire 23-h period.

\section{EXERCISE METABOLISM}

The lizards were fasted 2-3 days before exercise on the treadmill. At the onset of fasting, plastic collars for the attachment of respiratory masks were glued on to the necks with silicone sealant. Lizards were then placed in a temperature-controlled cabinet at 35-37 $\mathrm{C}$ under the previously established photoperiod. On the day of measurement of $\mathrm{VO}_{2}$ during exercise, clear plastic masks (snap-cap vials) were placed over the head and sealed to the collar. Air was drawn through the masks by the lizards for the remainder of the day. Flexible latex tubing was attached to the mask for routing of incurrent and excurrent air. The tubes were positioned above and in front of the exercising lizards so that the combined weight of the tubing and mask did not interfere with locomotion.

The lizards were run on a treadmill in a $37 \mathrm{C}$ room. All measures of $\mathrm{V}_{2}$ for exercising lizards were obtained during the first half of photophase during a 3-day period. $\mathrm{VO}_{2}$ was measured with the same open-circuit system described for the standard metabolic rate (SMR) measurements.

Each day several treadmill speeds were used for each lizard, the slowest speed being used first. Steady $\dot{\mathrm{VO}}_{2}$ values were typically obtained after 3-10 min of running. These steady-state values were then recorded at 30-s intervals for the next 4-14 min. If steady-state values were achieved at the slower speed, then treadmill speeds were increased gradually to the next desired level. Steady-state values were recorded as before. Cloacal temperatures of the lizards were measured on cessation of exercise. Lizards cooperated if treadmill speeds were not changed rapidly and if speeds were set at sustainable levels. Occasionally, a lizard could not be coaxed into walking even at low speed; these trials were discontinued for the day. We feel that we were unable to coax the lizards into attaining their maxi- 
mum aerobically sustainable speed since we could never fatigue individual lizards. Their refusal to walk with increased velocity was due to their behavioral disposition and not to exhaustion. In an attempt to elicit $\dot{\mathrm{V}}_{2_{\text {max }}}$, we agitated the lizards by prodding and grabbing them repeatedly. $\mathrm{V}_{2_{\max }}$ was obtained within the first couple of minutes.

\section{VENTILATION MEASUREMENTS}

We simultaneously measured gas exchange $\left(\dot{\mathrm{V}}_{2}, \dot{\mathrm{V}} \mathrm{CO}_{2}\right)$ and ventilation frequency $(f)$ and tidal volume (VT) in lizards fitted with masks and placed in a wholebody plethysmograph. A description of this system can be found in Bickler (1981). The lizards were fitted with the collars to the masks 2-3 days prior to a trial. Before an experiment, the lizards were placed in the plethysmograph and allowed 2-3 $\mathrm{h}$ to settle. During this time the $T_{\mathrm{b}}$ of the lizard (monitored via a fine thermocouple in the cloaca) was maintained at $25 \mathrm{C}$ by adjusting the temperature of the plethysmograph water jacket. Ventilation and gas exchange were then measured for $1 \mathrm{~h}$ at $25 \mathrm{C}$, during warming to $37 \mathrm{C}$ (duration of warming $=\sim 2 \mathrm{~h}$ ), and 2-3 $\mathrm{h}$ after $37 \mathrm{C}$ had been reached. We have not corrected tidal volume and gas exchange values for the differences in body mass among our specimens.

\section{RESULTS}

STANDARD METABOLISM

Standard $\dot{\mathrm{VO}}_{2}$ at different body temperatures is summarized in table 1 . There were no consistent differences in $\dot{\mathrm{V}}_{2}$ between lizards of different mass when these data were expressed on a mass-specific basis. The mean $\pm S E Q_{10}$ for standard $\dot{V}_{2}$ between 25 and $37 \mathrm{C}$ was $1.97 \pm 0.11$. $\mathrm{VO}_{2}$ 's from lizards with masks were three to four times greater than those in lizards without masks. Behaviorally, the masked lizards seemed to be asleep, but their bodies were not as limp as those of the unrestrained lizards.

\section{EXERCISE METABOLISM}

Overall, the regression equation relating speed to $\dot{\mathrm{VO}}_{2}$ was $\dot{\mathrm{VO}}_{2} \mathrm{ml} \mathrm{kg}^{-1} \mathrm{~h}^{-1}=3,144$ $+64 \mathrm{~m} \mathrm{~min}^{-1}(r=.28 ; n=20)$. When data for individual lizards were analyzed separately, however, velocity was significantly related to running speed (fig. 1). The most complete data set, that for a 37-g male, was described by the equation $\dot{\mathrm{V}}_{2} \mathrm{ml} \mathrm{kg}^{-1} \mathrm{~h}^{-1}$ $=1,990+111 \mathrm{~m} \mathrm{~min}^{-1}(r=.97 ; n=8)$.

$\dot{\mathrm{VO}}_{2_{\text {max }}}$ for Varanus gilleni was 5.4 liters $\mathrm{O}_{2} \mathrm{~kg}^{-1} \mathbf{h}^{-1}$. Table 2 contains a summary of standard and activity metabolism for $V$. gilleni, other varanids, and the iguanid Dipsosaurus dorsalis. Varanus gilleni has the highest weight-corrected aerobic capacity $\left(\dot{\mathrm{VO}}_{2_{\text {max }} \text { corr }}\right.$; factorial aerobic scope) of any lizard studied to date.

\section{VENTILATION}

Minute ventilation ( $\dot{\mathrm{V}} \mathrm{E})$ increased with temperature. This was due to augmentation in both ventilatory rate and tidal volume (fig. 2). Minute ventilation increased uniformly with temperature up to $37 \mathrm{C}$, and little or no further changes in ventilation were noted after 3-4 $\mathrm{h}$ at the final temperature. Thus, steady-state patterns were reached almost immediately, and no transient changes were seen with warming. Corresponding air-convection require-

TABLE 1

MEAN \pm SE STANDARD OXYGEN CONSUMPTION $\left(\dot{V}_{2}{ }_{2}\right.$; $\left.\mathrm{ml} \mathrm{O}_{2} \mathrm{STPD} /[\mathrm{kg} \cdot \mathrm{h}]\right)$ IN Varanus gilleni MEASURED AT CONSTANT TEMPERATURES

\begin{tabular}{|c|c|c|}
\hline \multirow{2}{*}{$\begin{array}{l}\text { BODY TEMPERATURE } \\
\left({ }^{\circ} \mathrm{C}\right)\end{array}$} & \multicolumn{2}{|c|}{$\underset{\text { LIZARDS }}{\operatorname{MEAN} \pm \underset{\mathrm{SE}}{\mathrm{VO}_{2}}(N) \text { OF }}$} \\
\hline & Masked & Unrestrained \\
\hline $\begin{array}{l}25-27 \ldots \ldots \ldots \ldots \\
31.0 \ldots \ldots \ldots \ldots \\
34.0 \ldots \ldots \ldots \ldots \\
36-37 \ldots \ldots \ldots \ldots\end{array}$ & $\begin{array}{c}372 \pm 48(4) \\
\ldots \\
\cdots \\
619 \pm 36(5)\end{array}$ & $\begin{array}{l}101 \pm 18(6) \\
126 \pm 6.6(3) \\
154 \pm 19.4(2) \\
195 \pm 11.4(5)\end{array}$ \\
\hline
\end{tabular}




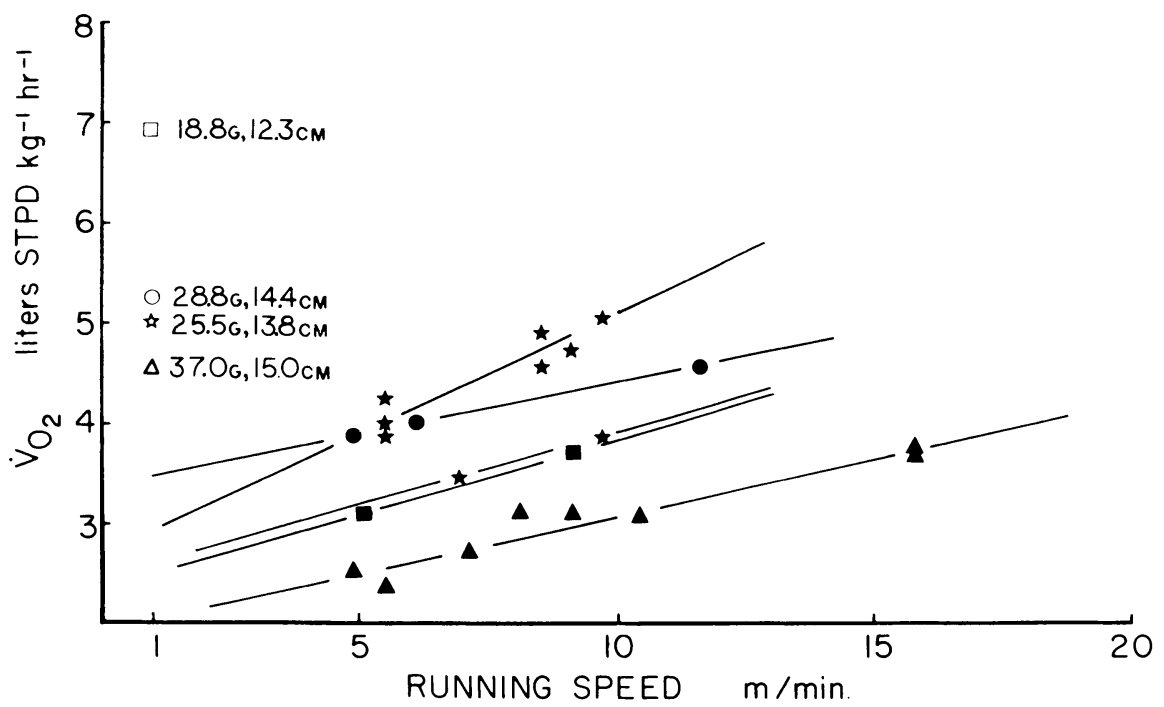

FIG. 1.- Relationship of weight-specific $\mathrm{VO}_{2}$ to running speed in individual Varanus gilleni (solid symbols). The lower line of stars represents the 25.5-g lizard at a later date. See Results for overall regression formula. Open symbols show $\mathrm{V}_{2_{\max }}$ produced by prodding the lizards to maximal activity; weight and snout-vent length are indicated next to these symbols.

ments $\left(\dot{\mathrm{V} E} / \dot{\mathrm{V}}_{2}\right)$ are shown in figure 3. These ratios were independent of temperature (analysis of covariance with $F$-test $=P$ $<.001)$. After reaching $37 \mathrm{C}$ little or no further changes in air-convection requirements were seen over the next several hours.
Hence, ventilation is quickly matched to gas exchange, and no time-dependent thermal acclimation of the respiratory system occurs within this range of temperatures and for these rates of temperature change. Mean \pm SE pulmonary respiratory ex-

TABLE 2

SUMMARY OF OXYGEN CONSUMPTION ( $\dot{\mathrm{V}}_{2}$ ), FACTORIAL AEROBIC SCOPE (STANDARD METABOLIC RATE [SMR]/ MAXIMUM $\mathrm{VO}_{2}\left[\dot{\mathrm{V}}_{2_{\max }}\right]$ ), AND WEIGHT-CORRECTED $\dot{\mathrm{V}}_{2_{\max }}\left(\dot{\mathrm{V}}_{2_{\max }}\right)$ IN VARANIDS AND Dipsosaurus dorsalis

\begin{tabular}{|c|c|c|c|c|c|c|c|}
\hline Species & $\begin{array}{l}\text { Mass } \\
(\mathrm{g})\end{array}$ & $\begin{array}{c}T_{\mathrm{b}} \\
\left({ }^{\circ} \mathrm{C}\right)\end{array}$ & $\begin{array}{c}\text { SMR } \\
(\mathrm{ml} \mathrm{O} /[\mathrm{g} \cdot \mathrm{h}])\end{array}$ & $\begin{array}{c}\dot{\mathrm{VO}_{2}} \\
\left(\mathrm{ml} \mathrm{O}_{2} /[\mathrm{g} \cdot \mathrm{h}]\right)\end{array}$ & $\begin{array}{c}\text { Factorial } \\
\text { Aerobic } \\
\text { Scope }\end{array}$ & $\begin{array}{c}\dot{\mathrm{VO}_{2}} \\
\left(\mathrm{ml} \mathrm{O} \mathrm{O}_{2} /[\mathrm{g} \cdot \mathrm{h} \cdot \mathrm{h}]\right)\end{array}$ & Reference \\
\hline \multicolumn{8}{|l|}{ Varanidae: } \\
\hline Varanus gilleni & 27.5 & 37 & .195 & 5.4 & 27.7 & 12.14 & Present study \\
\hline V. salvator & 505 & 35 & .144 & 1.10 & 7.6 & 4.90 & Gleeson 1981 \\
\hline$V \cdot$ gouldii & 674 & 35 & .10 & .76 & 7.6 & 3.63 & Bennett 1972 \\
\hline \multirow[t]{2}{*}{ V. exanthematicus ...... } & 1025 & 35 & .189 & 1.26 & 6.7 & 6.65 & $\begin{array}{l}\text { Gleeson et al. } \\
1980\end{array}$ \\
\hline & & 35 & $3.39 \mathrm{~W}^{-0.049}$ & & & 8.2 & $\begin{array}{l}\text { Wood et al. } \\
1978\end{array}$ \\
\hline \multicolumn{8}{|l|}{ Iquanidae: } \\
\hline \multirow[t]{2}{*}{ D. dorsalis } & 51.3 & 40 & & 2.00 & 15.4 & 5.75 & $\begin{array}{r}\text { John-Alder and } \\
\text { Bennett } 1981\end{array}$ \\
\hline & 35.2 & 40 & .13 & 2.27 & $17.5^{\mathrm{b}}$ & 5.53 & $\begin{array}{l}\text { Bennett and } \\
\text { Dawson } 1972\end{array}$ \\
\hline
\end{tabular}

a $\dot{\mathrm{VO}}_{2}$ war was calculated as $\dot{\mathrm{VO}}_{2} \cdot\left(\mathrm{g}^{0.76} \cdot \mathrm{h}\right)^{-1}$.

b Shocked electrically. 

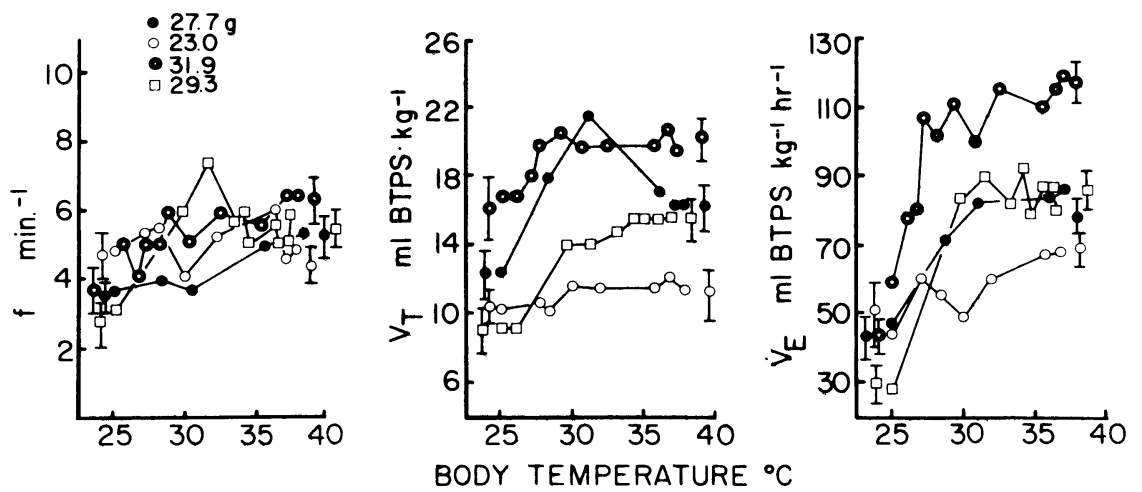

FIG. 2.-Ventilatory parameters from individual Varanus gilleni at $25 \mathrm{C}$ during warming to $37 \mathrm{C}$ and after 2-3 h at $37 \mathrm{C}$. Vertical bars denote SE.
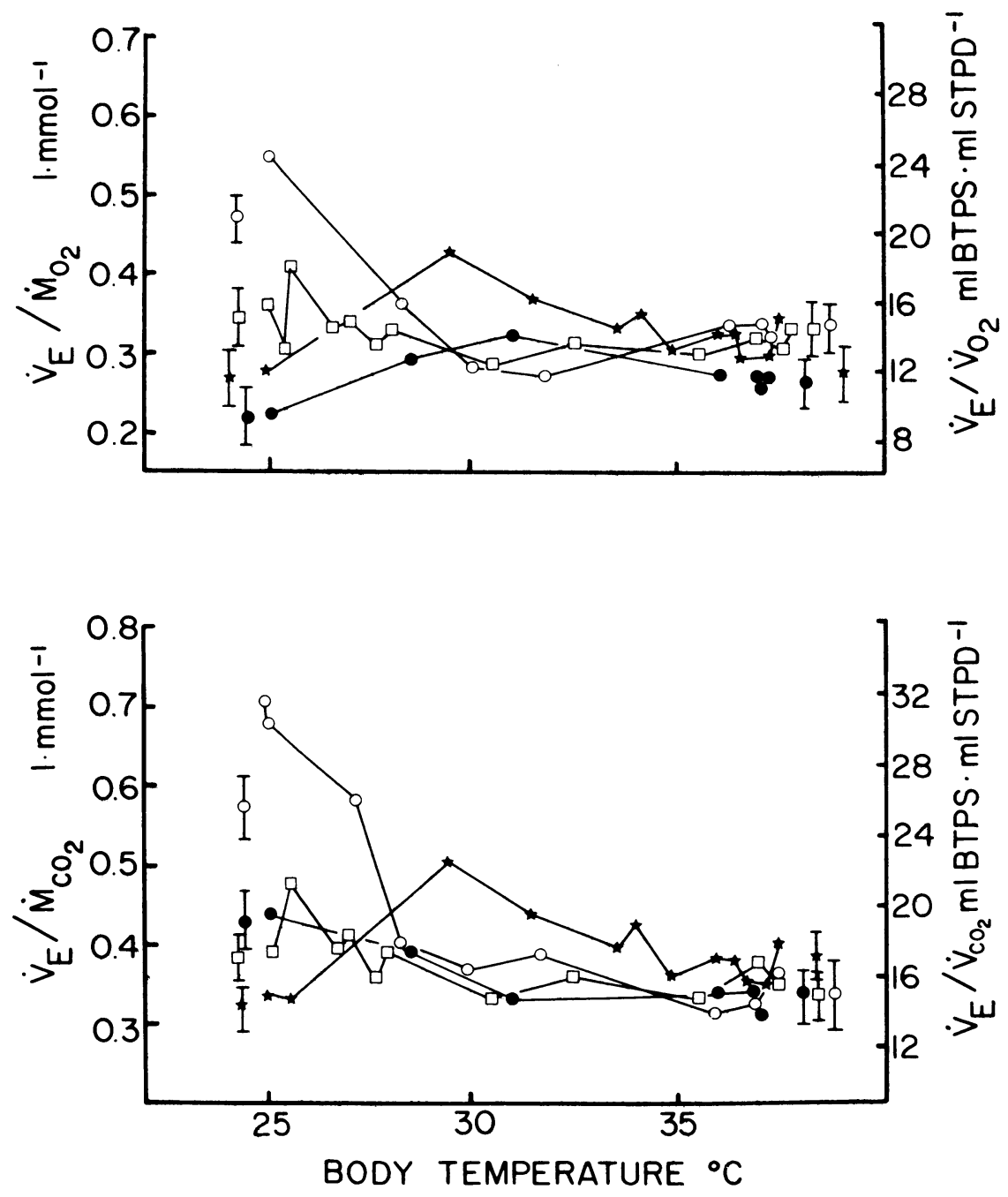

FIG. 3.-Air-convection requirements for Varanus gilleni at $25 \mathrm{C}$ during warming to $37 \mathrm{C}$ and after 2-3 h at 37 C. Vertical bars denote SE. 
change ratios $\left(\mathrm{RE} ; \dot{\mathrm{V}} \mathrm{CO}_{2} / \dot{\mathrm{V}}_{2}\right)$ were 0.75 \pm 0.03 at $25 \mathrm{C}$ and $0.72 \pm 0.05$ at $37 \mathrm{C}$. No significant transient values in RE were seen during or after the warming from 25 to 35 $\mathrm{C}$ (analysis of covariance with $F$-test for $P$ $<.05)$.

\section{DISCUSSION}

STANDARD METABOLISM

Our values for standard $\dot{\mathrm{V}}_{2}$ at $37 \mathrm{C}$ are $22 \%$ lower ( $194 \mathrm{ml} \mathrm{kg}^{-1} \mathrm{~h}^{-1}$ vs. 237$)$ than values predicted for lizard $\mathrm{VO}_{2}$ at $37 \mathrm{C}$ $\left(\log \mathrm{cm}^{2} \mathrm{O}_{2} \mathrm{~g}^{-1} \mathrm{~h}^{-1}=\log 0.424-18 \log \right.$ g) from Bennett and Dawson (1976). This regression is for lizards as a group. However, our values fall within the $95 \%$ confidence limits for that regression. Our values for SMR are somewhat lower than those for some other varanids previously studied (see Bartholomew and Tucker 1964; Louw, Young, and Bligh 1976; Gleeson, Mitchell, and Bennett 1980; Gleeson, 1981; and table 3).

In contrast to Bennett (1972), we noted substantial differences between the $\mathrm{V}_{2}$ 's of unrestrained and masked lizards. Our values for masked lizards at $37 \mathrm{C}$ are approximately three times those of controls and are near mean values predicted by the regression equation given by Wood et al. (1978). Wood's lizards were confined in cylinders and may not have been relaxed. At present, whether these differences in SMR between Varanus exanthematicus and unmasked $V$. gilleni are due to behavioral state or true differences in physiology is problematic.

\section{ACTIVITY METABOLISM}

Varanus gilleni exhibits one of the highest factorial aerobic scopes of any vertebrate studied to date, owing, in part, to its relatively low standard $\mathrm{V}_{2}$. Therefore, we do not believe that standard $\mathrm{V}_{2}$ bears any direct causal relationship to maximal aerobic capacity in lizards. Another striking example is that of the iguanid Dipsosaurus dorsalis. Its SMR is comparable to that of other iguanids, yet it greatly exceeds other family members in its aerobic capacity (table 3). At the other end of the spectrum is Physignathus lesueri (Agamidae; mean mass $=549 \mathrm{~g}$ ) with a similar resting metabolic rate (Wilson 1974) but less than one- half the $\dot{\mathrm{VO}}_{2_{\max }}$ of the similarly sized Amblyrhynchus cristatus (Iguanidae; mean mass $=580 \mathrm{~g}$ [Gleeson 1979]).

Gleeson (1979) presented the following equation for predicting the net cost of transport for lizards: $\mathrm{ml} \mathrm{O}_{2}=3.77$ mass $^{-0.25}$. The predicted value for $V$. gilleni (mean mass $=27.5 \mathrm{~g}$ ) is $1.65 \mathrm{ml} \mathrm{O}_{2} \mathrm{~g}^{-1}$ $\mathrm{km}^{-1}$. Using velocities close to those for which $\mathrm{VO}_{2}$ was measured for each lizard $\left(0.3 \mathrm{~km} \mathrm{~h}^{-1}, 5 \mathrm{~m} \mathrm{~min}^{-1}\right)$, we performed the conventional technique for obtaining the cost of transport for each lizard by subtracting the y-intercept value of $\dot{V}_{2}$ from the $\dot{\mathrm{V}}_{2}$ at $0.3 \mathrm{~km} \mathrm{~h}^{-1}$, then divided that value by $0.3 \mathrm{~km}$ to obtain the net cost of transport at that speed (John-Alder and Bennett 1981). The approximate mean net cost of transport for $V$. gilleni is $2.9 \mathrm{ml} \mathrm{O}_{2}$ $\mathrm{g}^{-1} \mathrm{~h}$, a value $75 \%$ higher than that predicted (Gleeson 1979). Varanus gilleni has rather short limbs $(20 \%$ shorter in front and $40 \%$ shorter in rear than Dipsosaurus dorsalis of similar mass), and this may increase the cost of transport.

The largest $V$. gilleni $(37.5 \mathrm{~g})$ ran for many minutes with no signs of fatigue at $1.0 \mathrm{~km} / \mathrm{h}$, a speed greater than the $0.8 \mathrm{~km} /$ $\mathrm{h}$ maximum aerobically sustained speed of D. dorsalis. We could not accurately determine the maximum speed continuously sustained by aerobic metabolism in $V$. gilleni.

Large home ranges and pursuit and excavation of vertebrate prey are ecological features common to large Varanus (Auffenberg 1978; Green and King 1978). Varanus gilleni, in contrast, eats gekkos and insects and is arboreal, secretive, and thigmothermic (Pianka 1969). The intense male-combat behavior of $V$. gilleni (Murphy and Mitchell 1974) seems to be the only factor in this species' behavioral repertoire that may require high aerobic capacity.

\section{PULMONARY VENTILATION}

Our values for air-convection requirements $\left(\dot{\mathrm{VE}} / \dot{\mathrm{V}}_{2}\right)$ in $V$. gilleni are only $\sim 35 \%$ of those in $V$. exanthematicus (table $3)$. This difference results from roughly comparable mass-specific ventilation values and much greater mass-specific metabolic rates in $V$. gilleni. While $f$ has no apparent correlation with body mass, VT scales with mass to the 0.85 power at $37 \mathrm{C}$ (Bennett 


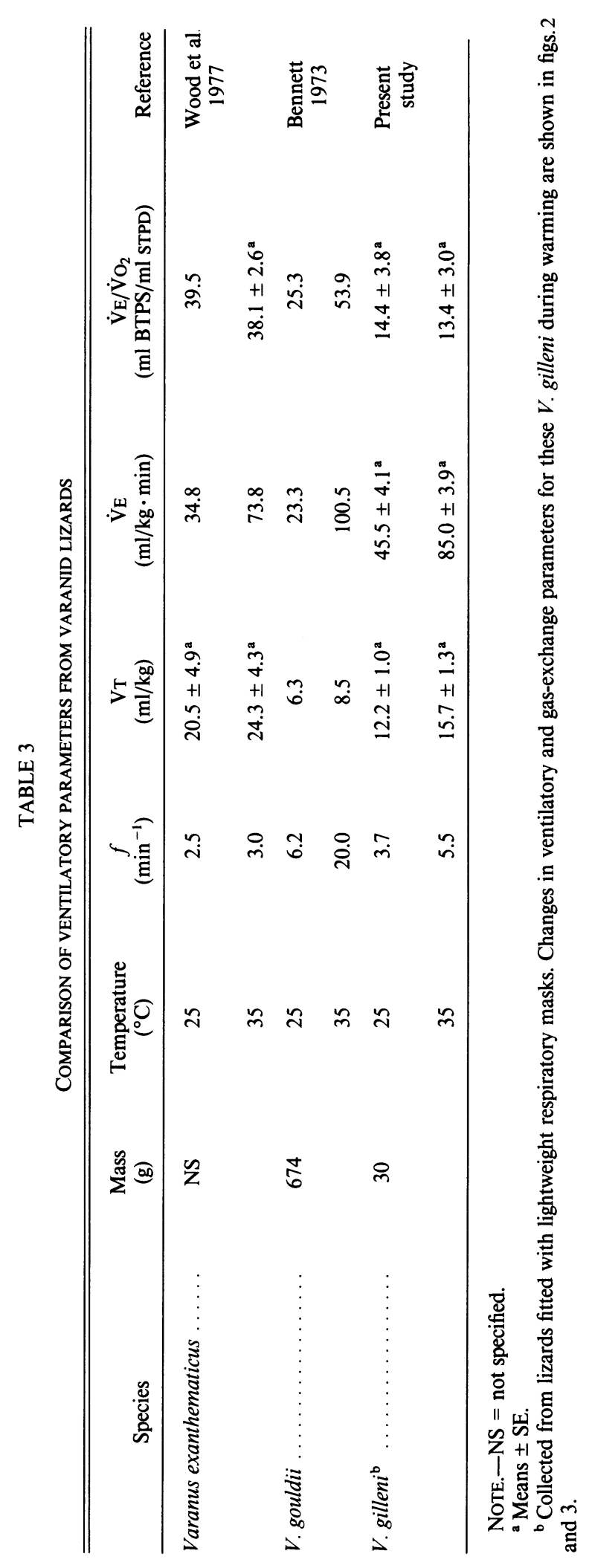


1973). Our tidal volume estimates for $V$. gilleni fall within the $95 \%$ confidence limits of Bennett's (1973) regression. The oxygen extraction efficiency $\left(\mathrm{EO}_{2}\right)$ was $68.6 \%$ at 25 $\mathrm{C}$ and $63.8 \%$ at $35 \mathrm{C}$ as calculated by the expression $\mathrm{EO}_{2}=\left(\dot{\mathrm{V}}_{2} / \mathrm{VE}\right)\left(100 \% / \mathrm{C}_{\mathrm{I}} \mathrm{O}_{2}\right)$, where $\mathrm{C}_{1} \mathrm{O}_{2}$ is the concentration of $\mathrm{O}_{2}$ in inspired air (Dejours 1981). In light of the spectacular aerobic capacity of $V$. gilleni, measurements of $\mathrm{O}_{2}$ extraction during activity would be of interest.

The $\dot{\mathrm{V}}_{\mathrm{A}} / \dot{\mathrm{V}}_{\mathrm{O}_{2}}\left(\dot{\mathrm{V}}_{\mathrm{A}}=\right.$ alveolar minute ventilation) value for $V$. exanthematicus from Wood et al. (1977) is 45.8 at $25 \mathrm{C}$ and $38.1 \mathrm{ml} \mathrm{BTPS} \mathrm{ml}^{-1}$ at $35 \mathrm{C}$, implying that arterial $\mathrm{PCO}_{2}$ was 17.1 torr at $25 \mathrm{C}$ and 21.8 torr at $35 \mathrm{C}$, as calculated from the gas equation and assuming a $\dot{\mathrm{V}} \mathrm{CO}_{2} / \dot{\mathrm{V}}_{2}$ of 0.80 .
Values for arterial $\mathrm{PCO}_{2}$ calculated in this way for $V$. gilleni at 25 and 37 are 43.8 and 42.0 torr. Our temperature-independent $\dot{\mathrm{VE}} / \mathrm{V} \mathrm{CO}_{2}$ values are consistent with the nearly constant arterial $\mathrm{PCO}_{2}$ and $\mathrm{pH}$ values that have been reported for $V$. exanthematicus (Wood et al. 1977, 1981). Constant blood $\mathrm{PCO}_{2}$ with rising temperature means that the total $\mathrm{CO}_{2}$ content of the blood decreases with rising temperature. Changes in the respiratory exchange ratio were not seen, however. This suggests that changes in the total $\mathrm{CO}_{2}$ content of the various body-fluid compartments, if they indeed occur, must involve exchanges between compartments rather than net changes in total $\mathrm{CO}_{2}$ content between the animal and environment via the respiratory system.

\section{LITERATURE CITED}

AUFFENBERG, W. 1978. Social and feeding behavior of Varanus komodoensis. Pages 301-331 in N. GREENBERG and P. P. MACLEAN, eds. Behavior and neurology of lizards. U.S. Dept. of Health, Education, and Welfare, National Institute of Mental Health, Rockville, Md.

BARTHOlOMEW, G. A., and V. A. TUCKeR. 1964. Size, body temperature, thermal conductance, oxygen consumption, and heart rate in Australian varanid lizards. Physiol. Zool. 37:341-354.

BENNETT, A. F. 1972. The effect of activity on oxygen consumption, oxygen debt, and heart rate in the lizards Varanus gouldii and Sauromalus hispidus. J. Comp. Physiol. 79:259-280.

$\rightarrow-$ 1973. Ventilation in two species of lizards during rest and activity. Comp. Biochem. Physiol. 46A:653-671.

BenNeTt, A. F., and W. R. DAwSON. 1972. Aerobic and anerobic metabolism during activity in the lizard Dipsosaurus dorsalis. J. Comp. Physiol. 81: 289-299.

- 1976. Metabolism. Pages 477-504 in C. GANS and W. R. DAwSON, eds. Biology of the reptilia. Vol. 5. Academic Press, New York.

BICKLER, P. E. 1981. Effects of temperature on acidbase balance and ventilation in desert iguanas. $J$. Appl. Physiol. 51:452-460.

DEJOURS, P. 1981. Principles of comparative respiratory physiology. 2d ed. Elsevier/North-Holland, Amsterdam.

GLEESON, T. T. 1979. Foraging and transport costs in the Galapagos marine iguana, Amblyrhynchus cristatus. Physiol. Zool. 52:549-557.

. 1980. Metabolic recovery from exhaustive activity by a large lizard. J. Appl. Physiol. 48:689694.

$\rightarrow-$ 1981. Preferred body temperature, aerobic scope, and activity capacity in the monitor lizard
Varanus salvator. Physiol. Zool. 54:423-429.

GleEson, T. T., G. S. Mitchell, and A. F. BENNETT. 1980. Cardiovascular responses to graded activity in the lizards Varanus and Iguana. Am. J. Physiol. 239:R 174-R179.

GreEN, B., and D. KING. 1978. Home range and activity patterns of the sand goanna Varanus gouldii (Reptilia: Varanadae). Aust. J. Wildl. Res. 5:417424.

JOHN-AlDER, H. B., and A. F. BENNETT. 1981. Thermal dependence of endurance and locomotory energetics in a lizard. Am. J. Physiol. 241:R342R349.

Louw, W. G., B. A. Young, and J. Bligh. 1976. Effect of thyroxine on thermoregulation, cardiac rate, and oxygen consumption in the monitor lizard Varanus albigularis albigularis. J. Therm. Biol. 1: 189-193.

MurPhy, J. B., and L. A. MitCHELL. 1974. Ritualized combat behavior of the pygmy mulga monitor lizard, Varanus gilleni (Sauria: Varanidae). Herpetologica 30:90-97.

PIANKA, E. R. 1969. Notes on the biology of Varanus caudolineatus and Varanus gilleni. West. Aust. Nat. 11:76-82.

WILSON, R. J. 1974. The relationship of oxygen supply for activity to body temperature in four species of lizards. Copeia 1974:920-934.

WITHERS, P. C. 1977. Measurement of $\dot{V}_{2}, \dot{V} \mathrm{CO}_{2}$ and evaporative water loss with a flow-through mask. J. Appl. Physiol. 42:120-123.

WoOD, S. C., M. L. Glass, and K. JohansEN. 1977. Effects of temperature on respiration and acid-base balance in a monitor lizard. J. Comp. Physiol. 116: 187-196.

WoOd, S. C., K. JohanSEN, M. L. Glass, and R. W. HOYT. 1981. Acid-base regulation during heating and cooling in the lizard, Varanus exanthematicus. J. Appl. Physiol. 50:779-783.

Wood, S. C., K. Johansen, M. L. Glass, and G. M. O. MALOIY. 1978. Aerobic metabolism of the lizard Varanus exanthematicus: effects of activity, temperature and size. J. Comp. Physiol. 127: 331-336. 